\title{
The determination of lignin
}

\author{
BY J. W. CZERKAWSKI \\ Hannah Dairy Research Institute, Ayr \\ (Received I4 Fuly I966-Accepted 29 November 1966)
}

\begin{abstract}
r. The methods for estimating lignin based on $72 \%$ sulphuric acid are lengthy and usually require large corrections for the residual nitrogenous impurities. The steps used in the initial purification of lignin, and particularly those concerned with the removal of nitrogenous impurities using proteolytic enzymes, have been investigated.

2. The conditions that remove the maximum amount of nitrogen were investigated. The nitrogenous material remaining in the lignin isolated by the adopted procedure was partly characterized, and it was shown that about half of the resistant $\mathrm{N}$ could be obtained in the form of amino acids which were presumably present in the lignin in the form of protein. The amino acid compositions of the resistant nitrogenous material in lignin derived from grass, and in lignin derived from faeces of sheep, when the same grass was given, were compared. They were found to be sufficiently similar to suggest a common origin.

3. A modified procedure is proposed and described in detail; it is suitable for routine work.

4. Comparisons were made between the results obtained by determining lignin in forage and faeces samples by the method now presented and those obtained by the method used previously.
\end{abstract}

Lignin occurs in plant tissue in close association with carbohydrate and possibly protein. It is a complex polymer of phenolic compounds, such as coumaryl alcohol and its derivatives (Freudenberg, 1965). The amount and the composition of lignin varies from plant to plant and depends very much on the age of any given plant species. Some of the structural units of lignin have been isolated in low yield (Bondi \& Meyer, 1948; Fischer, 1961), and the structure of lignin has been reviewed authoritatively by Freudenberg (1965). The aromatic nature of the constituent units suggests the possibility of spectrophotometric methods for the determination of lignin; such methods have been devised, but they are unreliable because of interference from associated impurities (Sowden \& DeLong, 1949).

Most of the commonly employed methods of isolation and estimation of lignin rely on treatment with ' $72 \% \mathrm{H}_{2} \mathrm{SO}_{4}$ ' as the major purification step (cf. Crampton \& Maynard, 1938; Ellis, Matrone \& Maynard, 1946). Many variations of this basic procedure have been described and examined critically, but it is impossible to review them here or even quote them all (Thomas \& Armstrong, I949; Moon \& Abou-Raya, I952a, $b$; Whitehead \& Quicke, 1964). Before treatment with sulphuric acid, it is necessary to remove most of the lipid and a large proportion of the nitrogenous impurities. Inefficient removal of nitrogenous impurities before treatment with $72 \%$ $\mathrm{H}_{2} \mathrm{SO}_{4}$ may lead to co-precipitation of humin with the result that abnormally high lignin values are obtained. With the exception of wood lignin, which is essentially free from nitrogenous impurities, the lignin isolated from most natural sources contains nitrogen which is usually presumed to be protein N (Thomas \& Armstrong, 1949). True lignin values are thus obtained by subtracting values for protein $(\mathrm{N} \times 6 \cdot 25)$ from crude lignin values. This protein correction often represents $15-30 \%$ of the crude 
lignin value to be corrected, and it is important that the protein correction factor should be as small as possible.

In the modification of the method for the determination of lignin described below, an attempt has been made to reduce the content of nitrogenous impurities in crude lignin to a minimum. Some observations on the nature of the nitrogenous impurities are also reported. A brief description of this modified method of determining lignin has been given by Czerkawski (1965).

\section{METHODS}

Ethanol-benzene $(\mathrm{I}: 2, \mathrm{v} / \mathrm{v})$.

\section{Reagents}

Dilute hydrochloric acid: $0.5,0.1$ and $0.02 \mathrm{~N}$ solutions were prepared.

Solution of pepsin: a $5 \%(\mathrm{w} / \mathrm{v})$ solution of Pepsin powder (British Drug Houses $\mathrm{Ltd}$, Poole) in $0.02 \mathrm{~N}-\mathrm{HCl}$ was prepared on the day of use.

Borate buffer solution, $\mathrm{pH} 8 \cdot 5: 12 \cdot 4 \mathrm{~g}$ boric acid (analytical reagent grade was dissolved in $\mathrm{r} 00 \mathrm{ml}$ of $\mathrm{r} \cdot \mathrm{O} \mathrm{N}-\mathrm{NaOH}$ and diluted to $\mathrm{r} \cdot \mathrm{O}$ 1. with water. This solution ( 7 vol.) was mixed with o.I $\mathrm{N}-\mathrm{HCl}$ solution (3 vol.).

Sodium dodecyl (lauryl) sulphate: an aqueous I \% (w/v) solution was prepared.

Solution of Pancreatin: $\mathrm{r} \circ \mathrm{g}$ Pancreatin (from pancreas; British Drug Houses Ltd, Poole) was suspended in $5 \mathrm{ml}$ of borate buffer solution; the mixture was stirred well and filtered. The residue was washed with two portions of $2 \mathrm{ml}$ buffer and the filtrate made up to $10 \mathrm{ml}$ to give a nominal $10 \%$ solution.

Sulphuric acid solution: a solution containing $72 \%$ (w/w) $\mathrm{H}_{2} \mathrm{SO}_{4}$ was prepared by adding $403 \mathrm{ml}$ conc. $\mathrm{H}_{2} \mathrm{SO}_{4}$ to $274 \mathrm{ml}$ water.

\section{Procedure}

Triplicate samples of about I $\mathrm{g}$ of the finely ground dried grass or other material were accurately weighed in extraction thimbles (Whatman single thickness, $25 \times 80 \mathrm{~mm}$ ). The samples were extracted for $2 \mathrm{~h}$ with ethanol-benzene in a Soxhlet apparatus. Sufficient heat was applied to give about five cycles of solvent/h. The solvent was removed under reduced pressure by placing the thimbles in rubber collars which were fitted into Buchner flasks. The samples were washed with acetone and then with diethyl ether. They were dried at $60^{\circ}$.

The dry residues were transferred quantitatively into $600 \mathrm{ml}$ beakers, $100 \mathrm{ml}$ of $0.5 \mathrm{~N}-\mathrm{HCl}$ were added, and the mixture was refluxed for $\mathrm{xh}$ under water-cooled round-bottom flasks. The supernatant solution was removed under reduced pressure with filter sticks (porosity 3 ; Baird and Tatlock Ltd) thinly coated with Celite filter aid. The residue was washed four or five times in the same way with $50 \mathrm{ml}$ hot water each time.

A total of $50 \mathrm{ml} 0.02 \mathrm{~N}-\mathrm{HCl}$ was added to the residue, forcing the first 5-10 $\mathrm{ml}$ of this solution down the filter sticks by means of compressed air. Pepsin solution $(\mathrm{I} \cdot \mathrm{\circ} \mathrm{ml})$ was added to each beaker and the mixture incubated at $37^{\circ}$ for $2 \mathrm{~h}$. The filter sticks were left in the beakers during incubation. The samples were filtered with filter sticks 
as before and washed with hot water. Borate buffer solution was then added, again forcing the first $5^{-10} \mathrm{ml}$ down the filter sticks. The remainder of the $50 \mathrm{ml}$ borate was used to wash the particles from the outside of the sticks which were then removed. Sodium dodecyl sulphate solution $(0.5 \mathrm{ml})$ was added and the mixtures were chilled by transferring the beakers to a refrigerator $\left(4^{\circ}\right)$ for $20 \mathrm{~min}$. A solution of Pancreatin $(\mathrm{r} \cdot \mathrm{\circ} \mathrm{ml})$ was added to each beaker and the suspensions were incubated at $37^{\circ}$ overnight. The suspensions were filtered under reduced pressure through strong filter paper (Whatman no. 52) held with clips in conical glass funnels in Buchner flasks as recommended by Waite, Johnston \& Armstrong (1964). The residues were washed several times with hot water, then with acetone and finally with diethyl ether. They were dried at $60^{\circ}$ and transferred quantitatively to weighing bottles $(2.5 \times 4.75 \mathrm{~cm})$ provided with well-fitting ground-glass caps, and $\mathrm{ro} \mathrm{ml}$ of $72 \% \mathrm{H}_{2} \mathrm{SO}_{4}$ solution were added. The bottles were shaken well and allowed to stand at room temperature for $2 \mathrm{~h}$. During that time they were shaken every $30 \mathrm{~min}$ (Waite et al. 1964).

After treatment with $72 \% \mathrm{H}_{2} \mathrm{SO}_{4}$, the contents of each of the weighing bottles were transferred to a $600 \mathrm{ml}$ beaker with a total of $240 \mathrm{ml}$ water and the diluted samples refluxed for $2 \mathrm{~h}$ with approx. $\mathrm{N}-\mathrm{H}_{2} \mathrm{SO}_{4}$. In the meantime, Gooch crucibles, prepared with a layer of asbestos, were heated in a muffle furnace at $55^{\circ}$ for $2 \mathrm{~h}$. Two of every replicate were then filtered while still hot through the crucibles and washed well with about $100 \mathrm{ml}$ hot water. The third sample was filtered through filter paper (Whatman no. 52) and was also washed well. The nitrogen content of the last sample was then determined by the Kjeldahl method.

The Gooch crucibles were dried at $105^{\circ}$ overnight, weighed, and their contents ashed by heating them in a muffle furnace at $55^{\circ}$ for $3 \mathrm{~h}$. The crucibles were weighed again and the weight of crude lignin was obtained by difference.

The amount of lignin, corrected for crude protein, and given on a dry-matter basis, was obtained from the equation:

$$
\operatorname{lignin}(\%)=\frac{5000}{D}\left(\frac{A_{2}}{W_{3}}+\frac{A_{3}}{W_{3}}-\frac{\mathrm{I} 2 \cdot 5 b}{W_{1}}\right),
$$

where $W_{1}$ is the weight of sample destined for $\mathrm{N}$ determination, $b$ is the weight of $\mathrm{N}$ in the lignin, $W_{2}$ and $W_{3}$ are the weights of the samples used for the lignin determination, $A_{2}$ and $A_{3}$ are the corresponding weights of the crude lignin and $D$ is the dry-matter content $(\%)$ of the material used.

\section{RESULTS}

\section{Investigation of steps used in purification of lignin}

Whereas some workers have favoured a prolonged extraction of lipid (Thomas \& Armstrong, I949), others have employed a shorter procedure (Moon \& Abou-Raya, I $952 a, b)$. It was decided to use a brief extraction period here, because there was less likelihood of loss of lignin. Under certain conditions lignin becomes partly soluble in organic solvents (Moon \& Abou-Raya, 1952a,b). A complete removal of lipid before treatment with $72 \% \mathrm{H}_{2} \mathrm{SO}_{4}$ is important, and it was considered that, in spite of the short extraction procedure adopted, the removal of lipid would be completed during the 
subsequent treatment with Pancreatin (see below). Treatment of the defatted material with $0.5 \mathrm{~N}-\mathrm{HCl}$ removes a large proportion of the $\mathrm{N}$ (see Table 2) and this step in the procedure was retained unchanged from that of Ellis et al. (1946).

Table I. Removal of nitrogen from a sample of dried grass using pepsin or Pancreatin

Treatment after extraction with ethanol-benzene or $0.5 \mathrm{~N}-\mathrm{HCl}$

\begin{tabular}{|c|c|}
\hline \multicolumn{2}{|c|}{ Nitrogen } \\
\hline $\begin{array}{c}\text { Content } \\
\text { (g/roo g dried } \\
\text { grass)* }\end{array}$ & $\%$ removed $\uparrow$ \\
\hline$I \cdot I 2$ & - \\
\hline 0.28 & 75 \\
\hline 0.26 & 77 \\
\hline$I \cdot I 4$ & 0 \\
\hline 0.20 & 82 \\
\hline 0.18 & 84 \\
\hline I'05 & - \\
\hline 0.74 & 30 \\
\hline 0.09 & $9 \mathrm{I}$ \\
\hline
\end{tabular}

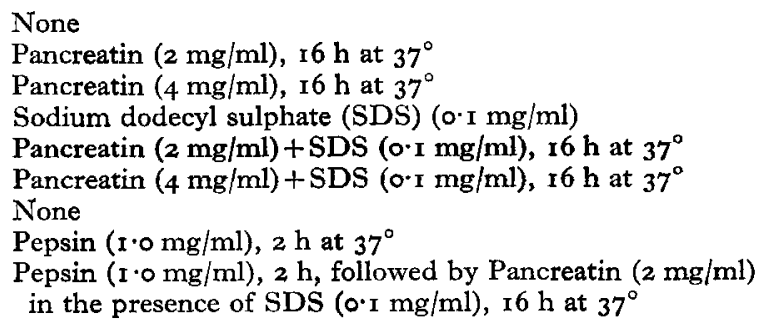

* The dried grass contained $2.05 \% \mathrm{~N}$ before lipid extraction and treatment with $0.5 \mathrm{~N}-\mathrm{HCl}$.

$\dagger$ Expressed as a percentage of the $\mathrm{N}$ left after lipid extraction and treatment with $0.5 \mathrm{~N}-\mathrm{HCl}$.

Pepsin (Sullivan, 1959) and trypsin (Armitage, Ashworth \& Ferguson, 1948) have been used to remove the protein during the isolation of lignin. Sullivan (I959) used $\mathbf{I}-\mathbf{2} \mathrm{g}$ of material, which presumably contained about I00 $\mathrm{mg}$ crude protein, with $400 \mathrm{mg}$ pepsin. Such abnormally high enzyme:substrate ratios could eventually lead to the co-precipitation of some of the enzyme. High concentrations of enzyme are unnecessary, as was shown during the present investigation. Samples of dried grass were defatted, treated with $0.5 \mathrm{~N}-\mathrm{HCl}$ as already described and dried. These large samples lost nearly half of their original $\mathrm{N}$ content during this treatment and were used in the investigation of the action of proteolytic enzymes. Amounts between 0.5 and $\mathrm{r} \cdot 0 \mathrm{~g}$ of the material were incubated with $5 \circ \mathrm{ml} 0.02 \mathrm{~N}-\mathrm{HCl}$ solution containing between 0.1 and $2.0 \mathrm{mg}$ pepsin $/ \mathrm{ml}$. The adopted procedure results in the removal of nearly $30 \%$ of the $\mathrm{N}$ present in the partly purified preparation, which corresponds to about $15 \%$ of the $\mathrm{N}$ originally present in the untreated sample. The pepsin step was much less efficient than the Pancreatin step (Table I), but it was included in the method because it improved the subsequent treatment with Pancreatin, as is shown later.

Pancreatin rather than trypsin was chosen for the next step. It is a mixture of proteolytic and other enzymes and so offers the possibility of a concerted action. Moreover, it contains lipases which would be expected to improve the removal of lipid. One of the causes of loss of lignin during incubation with trypsin could have been excessive alkalinity of the $0.25 \%$ solutions of $\mathrm{Na}_{2} \mathrm{CO}_{3}$ used by Armitage $e t$ al. (1948). During the present studies with Pancreatin the $\mathrm{pH}$ was kept constant by using borate buffer solutions of $\mathrm{pH} \mathrm{8.5}$. Samples of dried grass, defatted and treated with $0.5 \mathrm{~N}-\mathrm{HCl}$, were incubated with Pancreatin in borate buffer solution for periods up to $24 \mathrm{~h}$. When the concentration of Pancreatin was $2 \mathrm{mg} / \mathrm{ml}$ reaction mixture, the $\mathrm{N}$ content of the sample was reduced to about $25 \%$ of its value in $\mathrm{I} 6 \mathrm{~h}$ and then remained constant. 
This constant level of $\mathrm{N}$ was reached sooner (in 7-8 h) when $4 \mathrm{mg} / \mathrm{ml}$ Pancreatin were used, but when the enzyme concentration was increased to $8 \mathrm{mg} / \mathrm{ml} \mathrm{no} \mathrm{further} \mathrm{N}$ was removed, and in fact the constant remainder was larger than the one obtained with smaller amounts of enzyme. Thus nothing was gained by using large concentrations of Pancreatin and the concentrations used in the adopted procedure described above were optimal. Previous work (Hall \& Czerkawski, 1961) has shown that pretreatment of the solid protein substrate elastin with the anionic surface-active agent, sodium dodecyl sulphate, produced an increase in the proteolysis brought about by at least one powerful pancreatic enzyme, elastase. This was tested on the lignin impurityPancreatin reaction and it was found that addition of sodium dodecyl sulphate increased the activity of Pancreatin by about 10\% (Table I). This small effect corresponded to only $4 \%$ of the original $\mathrm{N}$ in the dried grass, but the step was included since it adds so little to the procedure time.

The proportion of the $\mathrm{N}$ removed during each step in the adopted procedure is shown in Table 2.

Table 2. Removal of nitrogen during isolation of lignin from dried grass, expressed as a percentage of the $N$ present originally

\begin{tabular}{lcc}
\multicolumn{1}{c}{ Treatment } & $\begin{array}{c}\text { N } \\
\text { remaining }\end{array}$ & $\begin{array}{c}\text { N removed } \\
\text { per step }\end{array}$ \\
None & roo & - \\
Defat; $0.5 \mathrm{~N}-\mathrm{HCl}$ & 53 & 47 \\
Defat; $0.5 \mathrm{~N}-\mathrm{HCl}$ + pepsin & 38 & 15 \\
Defat; $0.5 \mathrm{~N}-\mathrm{HCl}$ + pepsin + Pancreatin & 4 & 34 \\
Defat; $0.5 \mathrm{~N}-\mathrm{HCl}$ + pepsin + Pancreatin + & 2 & 2 \\
$72 \% \mathrm{H}_{2} \mathrm{SO}_{4} ;$ reflux & &
\end{tabular}

The $\mathrm{N}$ was determined at the end of each step shown in the table as described in detail on p. 327 .

\section{Characterization of nitrogenous impurity}

The procedure described above, when applied to grass and hay, gave purified lignin which still contained $2-3 \%$ of the $\mathrm{N}$ present initially. Lignin derived from faeces contained between 8 and $12 \%$ of the $\mathrm{N}$ originally present in the faeces. The question arose whether this resistant nitrogenous material was true protein (Thomas \& Armstrong, I949) or whether it was an integral part of the lignin (Bondi \& Meyer, I948). To investigate this point samples of dried grass lignin, and of faecal lignin derived from faeces of sheep given the same grass, were isolated by the adopted procedure. Samples (100 $\mathrm{mg}$ ) of the purified lignin were heated in sealed tubes with $2 \mathrm{ml}$ of $6 \mathrm{~N}-\mathrm{HCl}$ for $16 \mathrm{~h}$ at $105^{\circ}$. The contents of the tubes were diluted and filtered and the residues washed with water. The filtrate and washings were pooled, evaporated to dryness under reduced pressure and re-dissolved in water. The residues were hydrolysed twice more in the same way. The free $\alpha$-amino groups in the three extracts from grass and faecal lignin were estimated by the ninhydrin method of Moore \& Stein (1948), with alanine as a standard. The $\mathrm{N}$ content in the residues left after three extractions was determined by the Kjeldahl method. The results, expressed as proportions of the original $\mathrm{N}$ in the lignin samples, are given in Table 3. More than half of the resistant 
$\mathrm{N}$ could be removed as $\alpha$-amino- $\mathrm{N}$, presumably in the form of amino acids. Between 30 and $40 \%$ of the $\mathrm{N}$ remained in the residue, and some $10 \%$ was unaccounted for.

Similar samples were hydrolysed once with $6 \mathrm{~N}-\mathrm{HCl}$ and the hydrolysates were analysed by means of an automatic amino acid analyser (Evans Electroselenium Ltd, Halstead, Essex). The results are given in Table 4. The amino acid compositions of these two materials were similar with the exception of lysine and aspartic acid, both of which were presumably derived from bacteria and are more likely, therefore, to occur in the faeces. The amino acids accounted for $4 \mathrm{I}$ and $44 \%$ of the $\mathrm{N}$ in the grass and faecal lignin respectively. According to the results given in Table 4, the protein part of the nitrogenous impurity in grass and faecal lignin contained 15.2 and $16.8 \% \mathrm{~N}$ respectively, giving factors of 6.6 and 6.0 for converting $\mathrm{N}$ into crude protein. The average is close to the commonly used value of $6 \cdot 25$.

Table 3. Acid hydrolysis of purified lignins: the effects of repeated hydrolysis with $6 \mathrm{~N}-\mathrm{HCl}$ on the removal of nitrogen from lignin prepared by the procedure described in the text

$\begin{array}{lcc}\text { Treatment } & \text { (\% of N present originally) } \\ \text { rst hydrolysis } & \text { Grass } & \text { Faces } \\ \text { 2nd hydrolysis } & 44 & 47 \\ \text { 3rd hydrolysis } & 8 & 4 \\ \text { Total removed } & 4 & 3 \\ \text { Left in residue } & 56 & 54 \\ \text { Total recovery } & 36 & 34 \\ & 92 & 88\end{array}$

Table 4. Distribution of amino acids in lignins

\begin{tabular}{|c|c|c|c|}
\hline \multirow[b]{2}{*}{ Amino acid } & \multicolumn{2}{|c|}{$\begin{array}{c}\text { Amount present } \\
(\mu \text { moles/100 ml extract })\end{array}$} & \multirow[b]{2}{*}{ Ratio*, $b: a$} \\
\hline & $\begin{array}{l}\text { Grass lignin } \\
\quad(a)\end{array}$ & $\begin{array}{l}\text { Faecal lignin } \\
\text { (b) }\end{array}$ & \\
\hline Lys & $8 \cdot 5$ & $33 \cdot 2$ & 3.9 \\
\hline Arg & 10.0 & 25.5 & $2 \cdot 6$ \\
\hline His & $6 \cdot 0$ & I7.0 & $2 \cdot 8$ \\
\hline $\mathrm{NH}_{3}$ & $32: 0$ & $69 \cdot 7$ & $2 \cdot 2$ \\
\hline Asp & 10.0 & $57 \cdot 7$ & $5 \cdot 8$ \\
\hline Glu & $24 \cdot 4$ & $62 \cdot 2$ & $2 \cdot 5$ \\
\hline $\begin{array}{l}\text { Ser } \\
\text { Threo }\end{array}$ & $18 \cdot 5$ & $49 \cdot 9$ & $2 \cdot 7$ \\
\hline $\begin{array}{l}\text { 1 nfreo } \\
\text { Tyr }\end{array}$ & $\begin{array}{r}15.0 \\
4.5\end{array}$ & $\begin{array}{l}44 \cdot 2 \\
32 \cdot 7\end{array}$ & $\begin{array}{l}2.9 \\
2.8\end{array}$ \\
\hline Phe & $20 \cdot 0$ & 55.4 & $2 \cdot 8$ \\
\hline Pro & 24.5 & 67.5 & 2.8 \\
\hline Gly & 27.4 & $8 \mathrm{I} \cdot 5$ & 3.0 \\
\hline Ala & $29 \cdot 5$ & $70 \cdot 2$ & $2 \cdot 4$ \\
\hline Val & 15.4 & 55.2 & $3 \cdot 6$ \\
\hline Leu & 32.0 & $90^{\circ} 0$ & $2 \cdot 8$ \\
\hline Ileu & $15^{\circ} 0$ & $45^{\circ} \circ$ & $3 \cdot 0$ \\
\hline Met & 5.0 & I3.8 & $2 \cdot 8$ \\
\hline
\end{tabular}

\footnotetext{
* The ratio was sufficiently similar in most instances to suggest a common origin of amino acids in grass and in faecal lignins. The ratio was significantly greater in faecal lignin in three out of sixteen amino acids (values in bold-face type).
} 


\section{DISCUSSION}

\section{Assessment of the method}

Some of the results for lignin determined by the present method and by the method used previously in this laboratory (Waite et al. 1964) are given in Table 5. With the present method the correction for crude protein was small and represented only $5-8 \%$ of the crude lignin derived from the forages. It was somewhat larger in crude lignin derived from faeces (10-12\%). The method of Ellis $e t$ al. (1946) as modified by Waite et al. (1964) in our hands involved somewhat larger corrections in order to obtain the true lignin value. Nevertheless, the agreement in the values for the true lignin content obtained by the two methods was good with the exception of the values for a sample of young cocksfoot dried grass. Other methods (Thomas \& Armstrong, 1949; Fischer, 196I) require corrections amounting to between 10 and $25 \%$ of the crude lignin in both forages and faeces. Sowden \& DeLong (1949) used their standard method and the method of Crampton \& Maynard (1938) and found between 2.8 and $7.8 \% \mathrm{~N}$ in the lignin isolated from herbage. This corresponds to corrections amounting to between I 8 and $49 \%$ of the crude lignin value.

Table 5. Determination of lignin $(\%$, corrected for crude protein) in grass and faeces: comparison of the results obtained by the present method with those obtained by an earlier method

$\quad$ Sample
Cocksfoot (early cut)
Ryegrass (late cut)
Mixed dry grass
Faeces I
Faeces 2
Faeces 3

Earlier method*
$\begin{aligned} & 4.35(15) \\ & 7 \cdot 14(7) \\ & 4 \cdot 10(9) \\ & 17.2 \text { (16) } \\ & 20.1 \text { (15) } \\ & 13.5 \text { (23) }\end{aligned}$

Present method
$3 \cdot 74(8)$
$7 \cdot 20(5)$
$4 \cdot 32(6)$
$16 \cdot 1 \quad(12)$
$20 \cdot 3$ (10)
$13 \cdot 6$ (10)

The figures in parentheses are the correction factor for crude protein, expressed as a percentage of the crude lignin.

* Ellis et al. (1946), modified by Waite et al. (1964).

The amounts of $\mathrm{N}$ remaining in the purified lignin determined by the present method were small, but not negligible. According to the results reported here more than half of this $\mathrm{N}$ was present as protein, and the use of the factor 6.25 was at least partly justified.

The method has been used extensively in this laboratory in connexion with studies on rates of flow of digesta from rumen to abomasum (Ulyatt, Czerkawski \& Blaxter, I g66). The relative error of the mean of two duplicate determinations of faecal lignin (based on statistical analysis of thirty samples, with lignin contents ranging from $\mathrm{I} 2$ to $21 \%$ ) was $\pm 0.8 \%$ of the lignin value, and the relative error of the mean of two duplicate determinations of feed lignin (based on analysis of ten samples, with lignin contents between 4 and $9 \%$ ) was $\pm \mathrm{I} \cdot \mathrm{I} \%$. The present method of estimating lignin was used in twenty-seven digestibility trials (M. J. Ulyatt, unpublished results), and the recovery of lignin was $98 \cdot 9 \pm 1 \cdot 2 \%$. Admittedly, the method has lost little of its arbitrary nature. Nevertheless, one source of error and uncertainty, namely the 
correction factor for crude protein, has been reduced. The planning and timing of the various steps in the procedure require some thought, but it is possible for one person to estimate four different samples in 3 days or eight to ten samples in a week.

My thanks are due to Mrs C. Faulds for technical assistance and to Miss I. Fisher for assistance in the initial stages of the work. I am grateful also to $\mathrm{Dr} R$. Waite for providing samples of dried grass and faeces.

\section{REFEREN CES}

Armitage, E. R., Ashworth, R. de B. \& Ferguson, W. S. (1948). F. Soc. chem. Ind., Lond. 67, 241. Bondi, A. \& Meyer, H. (1948). Biochem. F. 43, 248.

Crampton, E. W. \& Maynard, L. A. (1938). F. Nutr. 15, 383.

Czerkawski, J. W. (1965). Proc. Nutr. Soc. 24, xviii.

Ellis, G. H., Matrone, G. \& Maynard, L. A. (1946). F. Anim. Sci. 5, 285.

Fischer, H. (1 961). K. LantbrHögsk Annlr 27, 465.

Freudenberg, K. (1965). Science, N.Y. 148, 595.

Hall, D. A. \& Czerkawski, J. W. (I96r). Biochem. F. 80, 128.

Moon, F. E. \& Abou-Raya, A. K. (I952a). \%. Sci. Fd Agric. 3, 399.

Moon, F. E. \& Abou-Raya, A. K. (1952b). F. Sci. Fd Agric. 3, 407.

Moore, S. \& Stein, W. H. (1948). F. biol. Chem. x76, 367.

Sowden, F. J. \& DeLong, W. A. (I 949). Scient. Agric. 29, 409.

Sullivan, J. T. (1959). F. Anim. Sci. 18, 2192.

Thomas, B. \& Armstrong, D. G. (1949). F. agric. Sci., Camb. 39, 335.

Ulyatt, M. J., Czerkawski, J. W. \& Blaxter, K. L. (1966). Proc. Nutr. Soc. 25, xviii.

Waite, R., Johnston, M. J. \& Armstrong, D. G. (I 964). F. agric. Sci., Camb. 62, 39 I.

Whitehead, D. L. \& Quicke, G. V. (I964). F. Sci. Fd Agric. 15, 4 I7. 